\title{
Development of lightweight concrete using industrial waste material, palm kernel shell as lightweight aggregate and its properties
}

\author{
U. Johnson Alengaram (Author), Hilmi Mahmud, Mohd Zamin Jumaat \\ Department of Civil Engineering, Faculty of Engineering \\ University of Malaya \\ Kuala Lumpur, Malaysia \\ Email: ujohnrose@yahoo.com
}

\begin{abstract}
Agricultural industrial wastes produced after extracting palm oil from palm fruits known as palm kernel shell (PKS) are available in large quantities in Indonesia, Malaysia, Nigeria and other tropical countries. Malaysia is the second largest palm oil producing country in the world. This paper reports the results of an investigation conducted to utilize the PKS as lightweight aggregate to produce grade30 concrete with density of about $1850 \mathrm{~kg} / \mathrm{m}^{3}$. The properties of both $P K S$ and crushed granite aggregates were compared. The concrete produced using PKS referred to here after as palm kernel shell concrete (PKSC) and its properties were compared with properties of normal weight concrete (NWC) of grade 30 produced using crushed granite aggregates. The fresh and hardened concrete properties such as density, workability, compressive strength of PKSC and NWC were compared. Further, structural behavior through flexural test was investigated. It has been found that PKSC has produced workable concrete and compressive strength of about 35MPa was obtained within 90 days. The addition of $10 \%$ silica fume has effect on both workability and strength. The as-cured density of PKSC was found $22 \%$ lower than the NWC. Further, the moment capacity of PKSC beams was found higher than NWC beams. In addition, the mode of failure observed in PKSC was ductile compared to the brittle failure of NWC beams.
\end{abstract}

Keywords-waste material, palm kernel shell, lightweight concrete, mechanical properties, flexural behaviour

\section{INTRODUCTION}

Concrete is used more than any other man-made material in the world. The high demand for concrete in the construction using normal weight aggregates such as gravel and granite drastically reduces the natural stone deposits and this has damaged the environment thereby causing ecological imbalance [1]. The use of synthetic lightweight aggregates from natural raw materials like clay, slate, shale etc., and from industrial by-products such as fly ash and slag ash hasn't been fully explored in developing and underdeveloped countries in Asia and Africa. However researches in these regions on the use of organic natural aggregate in the form of palm kernel shells (PKS) are on the rise. Ramli [2] reported that Malaysia alone produces nearly 4 million tons of PKS annually and this is likely to increase as more production is expected in the near future. It is causing environmental pollution as these are stored in open fields and research works to reuse the PKS for other purposes have been made. One of the reasons for use of such natural organic materials to produce concrete is the availability of such industrial by-products as waste materials.

In the previous research works on PKS concrete, the strength obtained was in the range of $20-26 \mathrm{MPa}[3,4,5,6]$. In this study, an attempt has been made to use PKS as a replacement of coarse aggregate to produce lightweight concrete (LWC). The main objective of this study is to produce grade $30 \mathrm{LWC}$ using PKS as lightweight aggregate and to compare the properties of palm kernel shell concrete (PKSC) with normal weight concrete (NWC) of similar grade. The properties studied include physical and mechanical properties of PKS and granite aggregates, fresh concrete properties such as density, workability and hardened concrete properties like compressive strength, flexural strength, splitting tensile strength, and modulus of elasticity. Further, the structural behavior of the PKSC and the NWC with respect to failure mode, ductility characteristic, moment capacity, crack width, and deflection was investigated and compared.

\section{MATERIALS AND MEOTHODS}

\section{A. Cement and Cementitious Materials}

Ordinary Portland cement with specific gravity of 3.10 was used for all mixes in this investigation. The class $F$ fly ash (FA) obtained from Lafarge Malayan Cement from Rawang, Selangor, Malaysia with $\mathrm{SiO}_{2}$ content of about $65 \%$ and relative density of 2.10 was used as cement replacement. Silica fume (SF) in undensified form with specific gravity of 2.10 was as additional cementitious material for mixes.

\section{B. Fine and Coarse Aggregates}

Mining sand of relative density of 2.7 was used as fine aggregates. It was dried and sieved to a particle size range between $0.15-2.36 \mathrm{~mm}$. The PKS obtained from local crude palm oil producing mill was used as coarse aggregates. Fig.1 shows crushed granite normal weight aggregates (NWA) and PKS. The PKS possess well distributed curved and irregular particles below $10 \mathrm{~mm}$; while NWA possessed particles between 5 and $20 \mathrm{~mm}$. Table 1 shows the comparison of physical properties between NWA and PKS. 


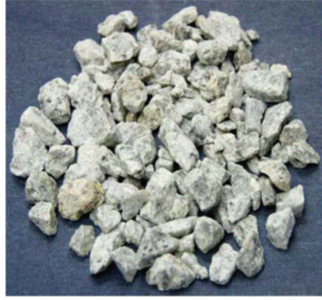

a) Crushed Granite Aggregate

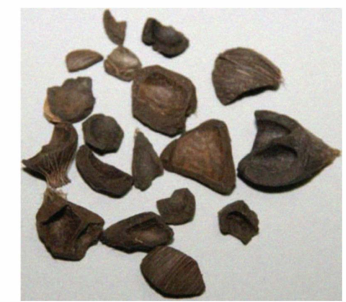

b) Palm Kernel Shell
Figure 1. Coarse Aggregates

TABLE I. COMPARISON OF PROPERTIES OF AGGREGATES

\begin{tabular}{|l|l|l|}
\hline Properties & NWA & PKS \\
\hline Thickness (mm) & 15 & $\approx 3.00$ \\
\hline Bulk density $\left(\mathrm{kg} / \mathrm{m}^{3}\right)$ & 1510 & 620 \\
\hline Specific gravity (SSD) & 2.67 & 1.37 \\
\hline Fineness modulus & 6.57 & 6.24 \\
\hline Water absorption - 24 hr (\%) & $<1$ & 24.5 \\
\hline Aggregate impact value (AIV) (\%) & 16.78 & 3.91 \\
\hline
\end{tabular}

\section{Sample Preparation}

The mix proportions for NWC and PKSC are given in Table 2. Concrete samples of NWC and PKSC were cast and cured in water until the day of testing. The following specimens were prepared: $100 \mathrm{~mm}$ cube for compressive strength; $100 \times 100 \times 500 \mathrm{~mm}$ prism for flexural strength and $150 \mathrm{~mm}$ diameter $\times 300 \mathrm{~mm}$ cylinder for the determination of Young's modulus. The mixing was done in the following order: firstly PKS in saturated surface dry condition was added with dry sand and mixed in mixer for about 2 minutes. Then cement and cementitious materials along with water with superplasticizer were added.

Two beams of same mix (NWC-FB1, NWC-FB2, PKSC-FB1, \& PKSC-FB2) as shown in Fig.2 were prepared. All beams were designed as under-reinforced in accordance with BS 8110:1997[7] to produce typical flexural mode of failure. The shear reinforcement for flexure was used only in the shear span at close spacing of about $75 \mathrm{~mm} \mathrm{c} / \mathrm{c}$.

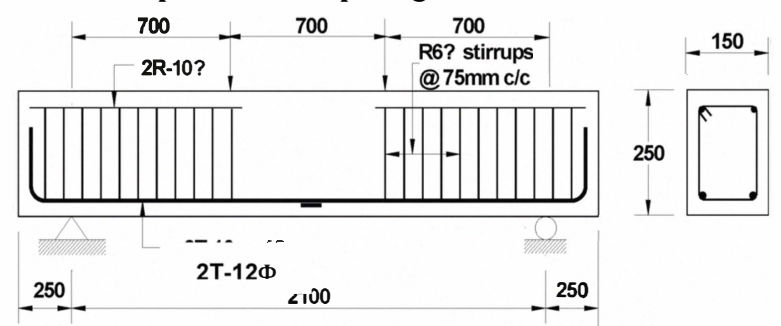

Figure 2 Reinforcement Details of Beam
TABLE II. MIX PROPORTIONS OF CONCRETE

\begin{tabular}{|c|c|c|c|c|c|c|}
\hline \multirow{2}{*}{ Mix } & Cement & Water & Sand & $\begin{array}{c}\text { PKS/ } \\
\text { NWA }\end{array}$ & FA & SF \\
\cline { 2 - 7 } & \multicolumn{6}{|c|}{$\mathrm{kg} / \mathrm{m}^{3}$} \\
\hline PKSC & 504 & 205 & 605 & 424 & 27 & 54 \\
\hline NWC & 315 & 205 & 1040 & 819 & 0 & 0 \\
\hline
\end{tabular}

\section{Testing of Concrete and Beams}

The fresh and hardened concrete properties were tested. It includes workability tests, compressive, and flexural strengths and modulus of elasticity. To investigate the structural behavior, the beams were simply supported and tested under two-point loading. The load from the actuator was transferred to the beam by means of a spreader beam. All the beams were loaded under two-point loads that were kept at $700 \mathrm{~mm}$ apart on a span of $2100 \mathrm{~mm}$. An Instron testing machine of capacity of $500 \mathrm{kN}$ with built-in load cell was used in the testing. Three linear voltage displacement transducers (LVDT) were placed, one at centre of the beam, the other two under load points, to measure the deflections.

\section{RESULTS AND DISCUSSION}

\section{A. Fresh Concrete Properties}

Table 3 shows fresh and hardened concrete properties. The density of PKSC was found about $1828 \mathrm{~kg} / \mathrm{m}^{3}$, while for the NWC it was about $2335 \mathrm{~kg} / \mathrm{m}^{3}$. Hence, the density reduction for PKS concrete is $22 \%$ on NWC is very useful in dead weight reduction. The density of the concrete depends on the particle density, sand content and type of sand used. The gravel aggregate is denser than PKS, so the density for NWC is always higher. The slump tests on NWC and PKS concrete produced true slump values of about $65 \mathrm{~mm}$ and $105 \mathrm{~mm}$, respectively. In order to increase the workability, superplasticizer was added to the mixture without changing the water cement ratio.

\section{B. Hardened Concrete Properties}

\section{i) Compressive Strength}

Fig. 3 shows the development of compressive strength up to an age of 90 days. The 28-day compressive strength of the PKSC was nearly 37MPa which was more than expected strength of $30 \mathrm{MPa}$. The inclusion of silica fume in the PKSC reacted with the liberated calcium hydroxide of cement and enhanced its strength.

TABLE III. FRESH AND HARDENED CONCRETE PROPERTIES

\begin{tabular}{|c|c|c|c|c|c|}
\hline Beam No. & $\begin{array}{c}\text { Cured } \\
\text { Density } \\
\left(\mathrm{kg} / \mathrm{m}^{3}\right)\end{array}$ & $\begin{array}{c}\text { Slump } \\
(\mathrm{mm})\end{array}$ & $\begin{array}{c}\text { Cube } \\
\text { strength } \\
(\mathrm{MPa})\end{array}$ & $\begin{array}{c}\text { Flexural } \\
\text { strength } \\
(\mathrm{MPa})\end{array}$ & $\begin{array}{c}\text { Young's } \\
\text { modulus } \\
\left(\mathrm{kN} / \mathrm{mm}^{2}\right)\end{array}$ \\
\hline NWC-FB1 & \multirow{2}{*}{2335} & \multirow{2}{*}{65} & 31.83 & 4.21 & 26.9 \\
\cline { 1 - 4 } \cline { 4 - 6 } NWC-FB2 & & 33.04 & 4.42 & 27.1 \\
\hline PKSC-FB1 & \multirow{2}{*}{1828} & \multirow{2}{*}{105} & 37.41 & 3.83 & 12.5 \\
\cline { 1 - 3 } & & 36.70 & 3.50 & 12.0 \\
\hline
\end{tabular}




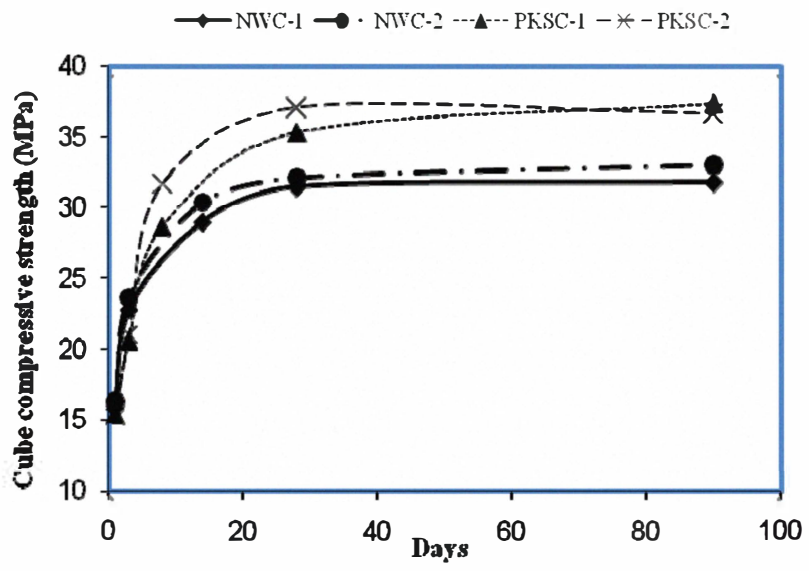

Figure 3 Development of Compressive Strength

Silica fume makes the concrete cohesive and influences stress transfer between aggregate and matrix. Fly ash generally influences later strength rather than early strength.

\section{ii) Flexural Strength}

The flexural strength for prism was tested at the age of 28 days. The average flexural strength of NWC was found about $4.58 \mathrm{MPa}$ or $14 \%$ of the 28 - day compressive strength. However, PKSC produced slightly lower flexural strength at the same age. The flexural strength of PKSC was found as $3.67 \mathrm{MPa}$ or $10 \%$ of its compressive strength. The variation in flexural strength between NWC and PKSC was mainly due to the lower strength and stiffness of the PKS. Gravel aggregates are very strong and stiff compared to PKS, in both compression and in tension. Generally, in NWC the failure in tension occurs as a result of breakdown of bond between the matrix and the surface of the aggregate or by fracture of the matrix itself, not as a result of fracture of the aggregate. However, the broken specimen from flexure tests showed the bond failure in addition to fracture of PKS along the path of tensile failure.

iii) Modulus of Elasticity

The modulus of elasticity increases with the cube strength and also the density of the concrete. The E-values of NWC and PKSC were found as $26.9 \mathrm{kN} / \mathrm{mm}^{2}$ and $12.5 \mathrm{kN} / \mathrm{mm}^{2}$, respectively. Thus the modulus of elasticity of PKSC was $47 \%$ as that of NWC. Generally, LWC produces lower E-values as the stiffness of lightweight aggregates (LWA) is lower compared to NWA. The E-values of LWC is generally falls in the range of $10-20 \mathrm{kN} / \mathrm{mm}^{2}$. Mannan [8] reported one-third E-values as that of NWC for oil palm shell (OPS) concrete in the range of $7-7.6 \mathrm{kN} / \mathrm{mm}^{2}$. However, the higher E-value found in this study was mainly due to cohesive mix produced by the addition of $10 \%$ silica fume and appropriate mix design that enabled higher modulus of elasticity of PKS concrete. As it is known, the E-value is influenced by stiffness of coarse aggregate and interfacial zone between aggregate and cement paste.

\section{Structural Behaviour}

i) Failure mode

The flexural failure mode was observed for the both NWC and PKSC beams as shown in Fig. 4. The yielding of steel took place and this was followed by crushing of concrete in the compression zone. Since all the beams were designed as under-reinforced, the failure started by yielding of the tension steel bar before the compression failure of concrete as expected. As can be seen from Fig.2, in order to ensure typical flexural failure, the shear and compression reinforcements were not provided in the pure bending region. Also, the stirrup spacing was kept at $75 \mathrm{~mm}$ centers in the shear zone and thus all beams failed in typical flexural mode.

For both types of concrete, failure started with flexural crack and extended to the neutral axis. The first flexural crack, after reaching the neutral axis, started to incline to form compression failure zone. And the crushing of concrete took place in that zone during failure. NWC concrete exhibited brittle failure; the prolonged deflection at maximum load of PKSC beam has given sufficient warning before final failure and thus the beam failed in ductile manner. However, the failure zone of PKSC was larger than NWC beams as seen from Fig.4.
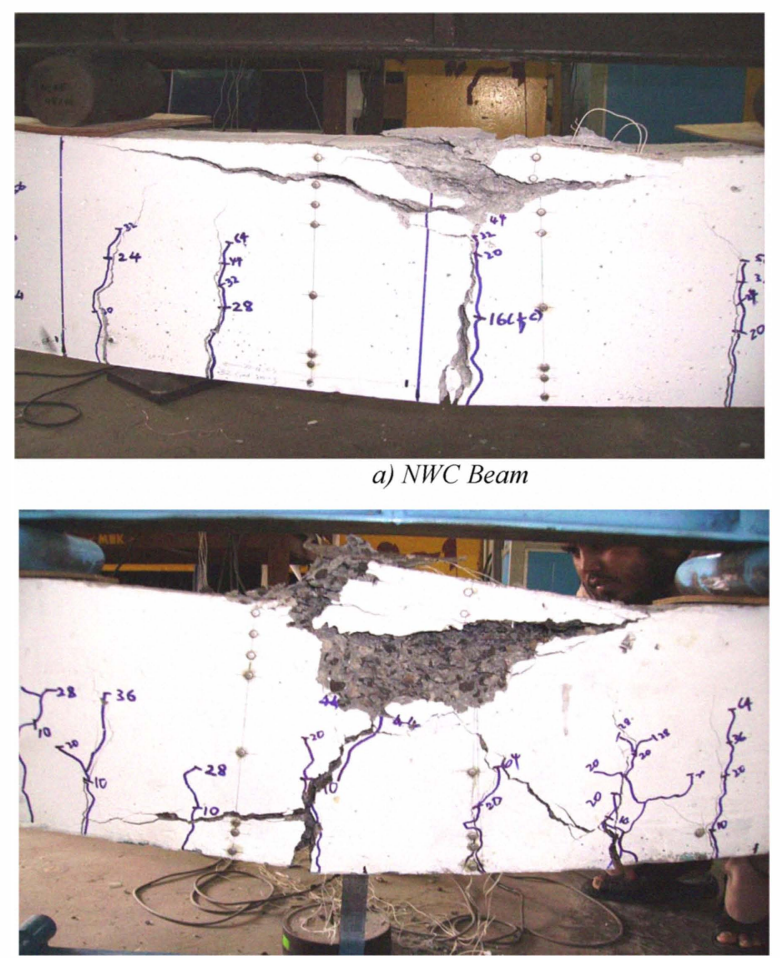

b) PKSC Beam

Figure 4 Failure Modes of Beams 
TABLE IV. Deflection Characteristics at SERVICE AND Ultimate Stages

\begin{tabular}{|c|c|c|c|c|c|c|}
\hline \multirow{3}{*}{ Beam designation } & \multicolumn{3}{|c|}{ Service stage } & \multirow{3}{*}{$\delta_{\text {ser }} / \delta_{\text {ser BS }}$} & \multicolumn{2}{|c|}{ Experimental deflection (mm) } \\
\hline & \multicolumn{2}{|c|}{ Experimental values } & \multirow{2}{*}{$\begin{array}{c}\begin{array}{c}\text { Predicted deflection } \\
\left(\delta_{\text {ser }}\right)_{\mathrm{BS}}(\mathrm{mm})\end{array} \\
\text { BS } 8110\end{array}$} & & \multirow{2}{*}{$\begin{array}{l}\text { Yield stage } \\
\qquad\left(\delta_{y}\right)\end{array}$} & \multirow{2}{*}{$\begin{array}{l}\text { Ultimate stage } \\
\qquad\left(\delta_{\mathrm{u}}\right)\end{array}$} \\
\hline & Moment (kN m) & $\begin{array}{c}\text { Deflection }\left(\delta_{\text {ser }}\right) \\
(\mathrm{mm})\end{array}$ & & & & \\
\hline NWC-FB1 & 14.09 & 5.25 & 5.03 & 1.04 & 14.81 & 42 \\
\hline NWC-FB2 & 14.16 & 5.40 & 5.04 & 1.07 & 18.49 & 51 \\
\hline PKSC-FB1 & 13.43 & 7.02 & 6.27 & 1.12 & 19.22 & 104 \\
\hline PKSC-FB2 & 14.29 & 6.99 & 6.59 & 1.06 & 18.79 & 79 \\
\hline
\end{tabular}

beams exhibited higher deflections than the NWC beams.

\section{ii) Deflection}

The experimental deflection at service stage has been compared with that of BS code. Table 4 shows the deflection at service, yield and ultimate stages. However, the experimental deflections at the service stage of both the PKSC and NWC beams are within the permissible limit of $8.4 \mathrm{~mm}$ as stipulated by the BS code for structural use.

Fig.5 shows the deflections at mid-span for all the four beams tested. As expected, the PKSC beams have shown higher deflections. This may be attributed to their lower stiffness of the PKSC compared to that of the NWC. Table 3 shows that the modulus of elasticity of PKSC is less than half that of NWC. Thus, the PKSC beams had undergone large deflections. It can also be seen that at early loads both NWC and PKSC beams behave linearly. Though the modulus of elasticity of PKSC is only $47 \%$ as that of NWC, at service loads, the deflections of both NWC and PKSC beams are much closer.

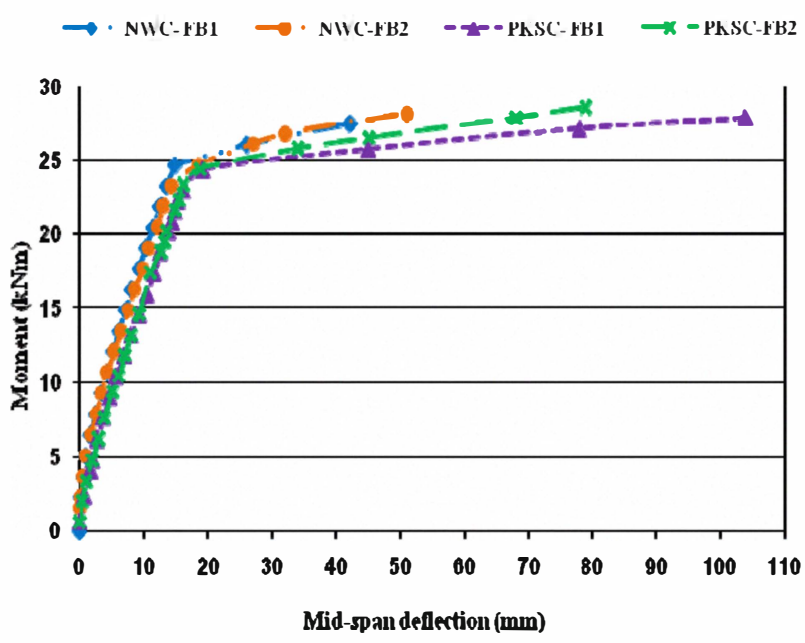

Figure 4 Deflections of Beams

The maximum deflections of the NWC beams were found to be between 40 to $50 \mathrm{~mm}$. However, the PKSC
The large deflections at near maximum load of the PKSC beams exhibit high ductile behaviour that may give ample warning before total collapse. However, the NWC beams failed in brittle manner as usual.

The maximum deflection prior to the final failure of the PKSC beams was found about $100 \mathrm{~mm}$ and this shows that the PKSC beams are highly ductile compared to the NWC beams. The ductility ratio, defined as the ratio between deflection at the ultimate and the yield stages, as given in the Table 4 shows that the PKSC beams have nearly twice the values as that of NWC beams. Thus, after the yielding of steel, the PKSC beams continue to show ductility by undergoing higher deflections without much increase in the load.

\section{iii) Ductility Characteristics}

The ductility ratio, defined as the ratio of deflection at ultimate stage to that at yield stage, was found to be nearly twice for the PKSFC and the PKSC beams, compared to the respective NWC beams. It has been mentioned by Ashour [9] that members with a ductility ratio of 3 to 5 has adequate ductility that can be considered for structural members subjected to large displacements, such as earthquake forces. A comparison of the ductility ratio of the PKSC-FB1 and the OPS concrete beam-S2 [10], both beams with similar reinforcement ratio show that the former has a higher ductility ratio of about $29 \%$.

\section{iv) Moment Capacity}

Table 5 shows the moment capacity of the PKSC and NWC beams tested under two-point loading. The theoretical ultimate moments were calculated using the ultimate strength of the reinforcement $\left(f_{t}\right)$ without any partial safety factor materials. It can be seen from the results that the experimental moments are nearly five percent higher than the theoretical calculations. The results show that the PKSC beams have slightly higher moment capacities than the NWC beams. 
TABLE V. Ultimate MOMENT AND CRACK WIDTH

\begin{tabular}{|c|c|c|c|c|c|}
\hline Beam & $\begin{array}{c}\text { Ultimate load } \\
(\mathrm{kN})\end{array}$ & $\begin{array}{c}\text { First crack width } \\
(\mathrm{mm})\end{array}$ & $\begin{array}{c}\text { Theoretical ultimate } \\
\text { moment } \mathrm{M}_{\mathrm{t}}(\mathrm{kNm})\end{array}$ & $\begin{array}{c}\text { Experimental ultimate } \\
\text { moment, } \mathrm{M}_{\mathrm{e}}(\mathrm{kNm})\end{array}$ & $\frac{\mathrm{M}_{\mathrm{e}}}{\mathrm{M}_{\mathrm{t}}}$ \\
\hline NWC-FB1 & 76.01 & 0.06 & 24.91 & 26.10 & 1.05 \\
\hline NWC-FB1 & 78.00 & 0.06 & 25.08 & 26.81 & 1.07 \\
\hline PKSC-FB1 & 77.47 & 0.06 & 25.62 & 26.72 & 1.04 \\
\hline PKSC-FB2 & 81.09 & 0.02 & 25.54 & 28.99 & 1.09 \\
\hline
\end{tabular}

\section{CONCLUSIONS}

The following conclusions are drawn from the experimental results:

1) PKS possesses hard characteristics as coarse aggregate, and hence it can be used as coarse aggregates to produce grade 35 PKSC.

2) The aggregate impact value of PKS was very low compared to normal granite aggregates and this shows higher resistance against impact.

3) PKSC results in a density reduction of about $22 \%$ compared to NWC. The compressive strength of PKSC was $12 \%$ higher compared to NWC.

4) Though the modulus of elasticity of PKSC was found about $12 \mathrm{kN} / \mathrm{mm}^{2}$ which was $47 \%$ of NWC, the deflection of PKSC beams was within limits.

5) The failure of PKSC was governed by the crushing of PKS and bond failure.

6) The overall flexural behavior of reinforced PKSC beams used in this study closely resembles that of equivalent beam made with NWC.

7) Lower modulus of rupture of PKSC resulted in early cracks in PKSC beam. However, the close spacing and large number of cracks in PKSC beams resulted in lesser crack widths than the NWC beams. The crack widths of the PKSC at service loads are within the durability requirements of BS 8110 .

8) The deflection of the PKSC beams at service loads were close to the deflection of the NWC beams. However, the large deflections at near maximum load of the PKSC beams exhibited high ductile behavior that gave ample warning before total collapse.

9) The ultimate moment of the PKSC beams were closer to that of the NWC beams and in the case of the PKSC-B2, the ultimate moment was higher than that of the NWC beams.

10) The PKSC beams had sufficient ductility and the failure zone was distinctly larger than the NWC beams.

\section{ACKNOWLEDGMENT}

This research work is funded by University of Malaya under Research Grant (UMRG) no. RG 085/10AET.

\section{REFERENCES}

[1] A. Short and W. Kinniburgh, Lightweight Concrete. $3^{\text {rd }}$ edn., London: Applied Science Publication, 1978

[2] A. Ramli, "Short-term and long-term projection of Malaysian palm oil production", Oil Palm Industry Economic Journal, Vol. 3, 2003, pp. 32-36.

[3] A.A. Abdullah, Palm oil shell aggregate for lightweight concrete. Waste Materials Used in Concrete Manufacturing. In: Chandra S., and Berntsson. L. editors. Lightweight Aggregate Concrete, Science, Technology, and Applications. $1^{\text {st }}$ edn. New York: Noyes Publications, 2003.

[4] D.C. Okpala, "Palm kernel shell as a lightweight aggregate in concrete" Building and Environment, Vol.25, 1990, pp. 291296.

[5] H.B. Basri, M.A. Mannan and M.F.M. Zain, "Concrete using waste oil palm shells as aggregate", Cement and Concrete Research, Vol. 29, 1999, pp. 619-622.

[6] E.A. Olanipekun, K.O. Oluola and O. Ata, "A comparative study of concrete properties using coconut shell and palm kernel shell as coarse aggregates", Building and Environment, Vol. 41, 2006, pp. 297-301.

[7] BS 8110: Part 1: 1997, Structural use of concrete. Code of practice for design and construction, London: British Standards Institution, 1997.

[8] M.A. Mannan, and C. Ganapathy, "Engineering properties of concrete with oil palm shell as coarse aggregate", Construction and Building Materials, Vol. 16, 2002, pp. 29-34.

[9] S.A. Ashour, 2000). "Effect of compressive strength and tensile reinforcement ratio on flexural behavior of highstrength concrete beams", Engineering Structures, Vol. 22, 2000, pp. 413-423.

[10] D.C.L. Teo, M.A. Mannan and J.V. Kurian, "Flexural behavior of reinforced lightweight concrete beams made with oil palm shell (OPS)", Journal of Advanced Concrete Technology, Vol. 4, 2006, pp. 1-10. 